Kónya P.

Rektor Prešovská Univerzita, PhDr., Professor

Štefko R.

Dekan Fakulty manažmentu Prešovskej, Ph.D., Professor,

\title{
HIGHER EDUCATION OF THE SLOVAK REPUBLIC IN THE CONTEXT OF EUROPEAN INTEGRATION
}

The beginning of the third millennium was marked by Bologna Declaration adoption, in which the cardinal changes and systemic reforms in the educational process development were declared. The countries participants agreed on the creation of a single European educational and scientific space and formulated unified requirements, criteria and standards of national higher education systems development and reform. The Slovak Republic and Ukraine officially joined the Bologna Process, and thus carry out structural reform of higher education and bring its standards in line with the pan-European ones. The reform's goal is to create attractive and competitive national higher education systems integrated into the European Higher Education Area and the European Research Area.

The outlined trends increase attention to the issues of training specialists in the Slovak Republic, which are capable of working effectively in modern conditions.

Institutional transformations in sphere of education and science of the Slovak Republic are based on the following innovations:

- to improve the higher education system structure, the essence of which is the structural development of the national higher education system in accordance with the International Standard Classification of Education;

- the formation of a quality assurance system in higher education that will meet the recommendations and standards of the European Higher Education Area and adapt international world practices; creation of a modern system of external and internal (universal) quality assurance in higher education, reforming of funding systems, introduction of a real procedure for challenging student evaluation results; 
- development of mechanisms for ensuring the autonomy of institutions in higher education, the essence of which is to expand the academic and, in part, organizational autonomy of institutions of higher education;

- modernization of the higher education content, updating of the contents and forms of organization of the educational and educational process; optimization of workers retraining system and increase their qualification, modernization of postgraduate education system; creation of integrated curriculums and programs; distance education development; organization of training in accordance with the needs of the individual and the labor market

- reforming the system of higher education financing and increasing the efficiency of public spending on higher education without significantly increasing their share in the consolidated budget of the state in order to meet the needs of society and economy in specialists with higher education and guaranteed provision of quality higher education for capable persons. Also, other modern forms of public financing of higher education should come to replace the state order system;

- development and implementation of programs for the integration of higher education and science, which should be achieved by increasing the share and quality of research and innovation activities in higher education institutions. It should be noted that the triad «education-scienceproduction» is an integral part of the basic principles of state economic progress, which we traditionally refer to as «developed». It is precisely for it that it is the economic development foundation, and hence of the sphere of services, finance, economic cooperation, etc. Higher education thus creates preconditions for welfare improvement.

- solving the problem of the management system de-bureaucratization, reducing the activity of the institutional bodies in the sphere of education to international norms and requirements and significantly reorganizing the educational institution work;

- internationalization, achieving an appropriate level of openness and transparency and institutional improvement of education and science

Within this space, there should be common requirements for the recognition of diplomas about education, employment and citizen's mobility, which will significantly increase the competitiveness of the European labor market and educational services. 
Consequently, the reform of national higher education systems will ensure integration into the European educational space, high-quality and competitive professional training of specialists, will become the driver for the implementation of educational trajectories with applied, research, scientific-practical and scientific-pedagogical bias.

\section{List of bibliographic references}

1. lifeinslovakia.com - Technology info . available at: https://www. google.com/url?sa $=$ t\&rct $=\mathrm{j} \& \mathrm{q}=\&$ esrc $=\mathrm{s} \&$ source $=$ web\&cd $=$ 